\title{
Optimalisasi Handover Jaringan 4G Telkomsel di Kota Palembang
}

\author{
Muhamad Ilham Afwan, Nasron, Suroso \\ Jurusan Teknik Elektro, Teknik Telekomunikasi Politeknik Negeri Sriwijaya, Palembang, Indonesia \\ Jl.Srijaya Negara, Bukit Lama, Kec. Ilir Barat I, Kota Palembang 30139 \\ m.ilhamafwan@gmail.com,nasron6819@gmail.com, osorus11@gmail.com
}

\begin{abstract}
Handovers on $4 G$ networks such as Hard Handover when downlink and uplink must run well, if not then ongoing downlinks and uplinks will be hampered and even fail. This is closely related to potential customer satisfaction, thus the possibility of a handover failure resulting in dissatisfaction with operator users. Along with the high customer interest in $4 G$ LTE technology, this makes Telkomsel cellular operators maintain Quality \& Performance where there is a decline in the quality of RSRP \& SINR. One effort is to measure data in the field. The method in measuring data in the field is a Test Drive. Test Drive is a measurement method in a mobile communication system that aims to collect data on the measurement of signal quality of a network from the real direction in the field, so that it can know how the performance of the network
\end{abstract}

Keywords: 4G-LTE, Handover, Downlink, Uplink, Test Drive

\section{Abstrak}

Handover pada jaringan $4 G$ seperti Hard Handover pada saat downlink dan uplink harus berjalan dengan baik, jika tidak maka downlink dan uplink yang sedang berlangsung akan terhambat bahkan akan gagal. Hal ini terkait erat dengan potensi kepuasan pelanggan, dengan demikian kemungkinan adanya kegagalan handover sehingga terjadi ketidakpuasan pada pengguna operator. Seiring dengan tingginya minat pelanggan terhadap teknologi 4G-LTE, hal ini membuat operator seluler Telkomsel harus tetap menjaga Quality \& Performance dimana terjadinya penurunan kualitas RSRP \& SINR. Salah satu upaya yang dilakukan adalah mengukur data dilapangan. Metode dalam pengukuran data dilapangan adalah Drive Test. Drive Test adalah metode pengukuran pada sistem komunikasi bergerak yang bertujuan untuk mengumpulkan data hasil pengukuran kualitas sinyal suatu jaringan dari arah real di lapangan, sehingga dapat diketahui bagaimana performansi dari jaringan tersebut

Kata kunci: 4G-LTE, Handover, Downlink, Uplink, Drive Test

\section{PENDAHULUAN}

Perkembangan teknologi telekomunikasi membuat akan haus informasi yang cepat dan akurat,dan dituntut agar dapat memenuhi komunikasi dengan laju data yang tinggi, kapasitas yang besar, area akses yang semakin luas, dan mobilitas yang tinggi. Hal tersebut dilihat dari sisi pelanggan, sedangkan dari sisi penyedia jaringan diperlukan desain jaringan yang lebih sederhana namun dapat bekerja dengan seoptimal mungkin.

Teknologi 4G-LTE memiliki kecepatan transfer data yang cepat (100Mbps $1 \mathrm{Gbps}$ ) sehingga dapat melayani data broadband seperti internet, video on demand, 
music on demand, games on demand, downlink and uplink on demand yang memungkinkan kita dapat memilih program musik, video, games, downlink atau, uplink. Kecepatan tinggi tersebut juga mampu melayani video conference dan video streaming lain. Sebagaimana generasi sebelumnya, pada jaringan 4G terdapat juga handover. Handover adalah suatu mekanisme yang memungkinkan user pindah pelayanan dari suatu sektor ke sektor lain baik dalam sutu BTS maupun antar BTS tanpa adanya pemutusan hubungan dan terjadi pemindahan frekuensi/kanal secara otomatis yang dilakukan oleh sistem[1].

Seiring dengan tingginya minat pelanggan terhadap teknologi 4G-LTE, hal ini membuat operator seluler Telkomsel harus tetap menjaga Quality \& Performance dimana terjadinya penurunan kualitas RSRP \& SINR. Salah satu upaya yang dilakukan adalah mengukur data dilapangan. Metode dalam pengukuran data dilapangan adalah Drive Test. Drive Test adalah metode pengukuran pada sistem komunikasi bergerak yang bertujuan untuk mengumpulkan data hasil pengukuran kualitas sinyal suatu jaringan dari arah real di lapangan, sehingga dapat diketahui bagaimana performansi dari jaringan tersebut.

\section{METODOLOGI PENELITIAN}

Menjelaskan kronologis penelitian termasuk cara menyiapkan bahan penelitian, rancangan atau desain penelitian, prosedur penelitian (dalam bentuk algoritma, pseudocode atau lainnya), cara pengujian dan pengambilan data. Pada bagian ini boleh juga diberikan dasar teori. Tabel dan Gambar dibuat center seperti di bawah ini dan diacu pada naskah.

\subsection{Perancangan Penelitian}

Kerangka tahapan penelitian dibuat dengan blok diagram sistem secara keseluruhan. Blok diagram merupakan salah satu bagian terpenting dalam perancangan penelitian, karena blok diagram rangkaian ini lah dapat diketahui cara kerja atau tahapan proses sebuah penelitian[2]. Sehingga keseluruhan blok diagram perancangan penelitian akan menghasilkan suatu sistem yang dapat difungsikan dan digunakan sebagai acuan. Gambar 1 menunjukan kerangka perancangan penelitian secara keseluruhan. 


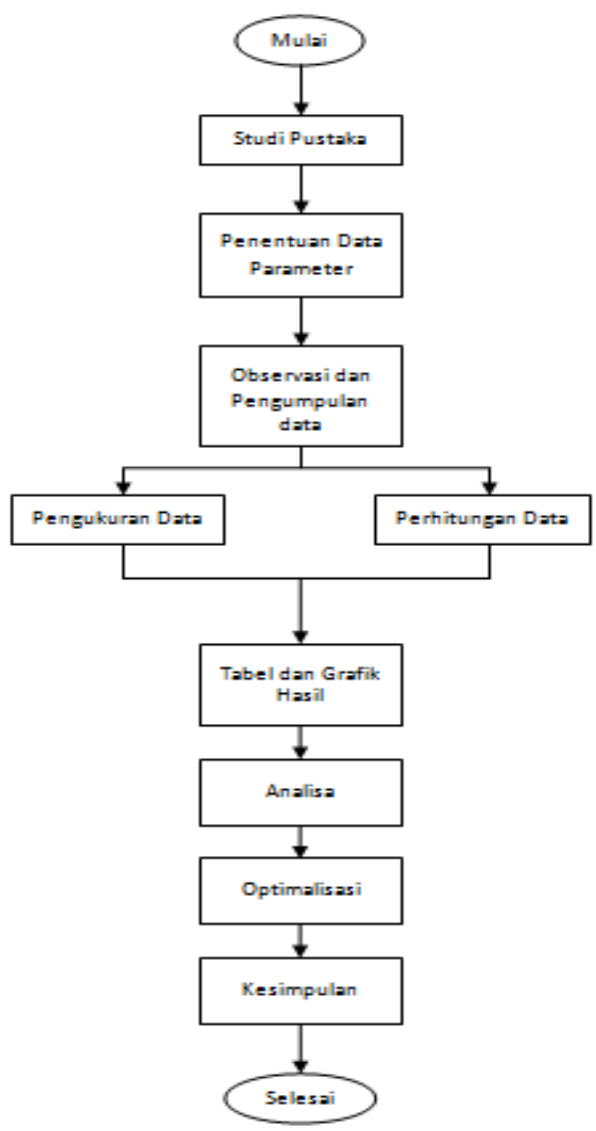

Gambar 1. Flow Chart Kerangka Penelitian

\subsection{Penentuan Data Parameter}

Parameter yang telah ditentukan berdasarkan pengumpulan informasi tentang handover komunikasi jaringan 4G-LTE, yaitu:

a. RSRP (Reference Signal Received Power)

RSRP adalah power dari sinyal yang diterima dari eNodeB ke User Equipment.

b. SINR (Signal to Interference Noise Ratio)

SINR merupakan ratio antara rata-rata power yang diterima dengan rata-rata interferensi dan noise. Minimum RSRP dan SINR yang sesuai tergantung pada band frekuensinya.

c. THROUGHPUT

THROUGHPUT adalah jumlah bit persatuan waktu yang diterima oleh suatu terminal tertentu di dalam sebuah jaringan. Throughput memiliki satuan bit per second (bps). System throughput atau jumlah throughput adalah jumlah rata-rata bit yang diterima untuk semua terminal pada sebuah jaringan[3].

d. PCI (Physical Cell ID)

PCI merupakan cara untuk mengidentifikasi pada fisik cell dalam jaringan 4GLTE. Setiap cell melakukan broadcast penandaan identifikasi berupa PCI yang digunakan oleh perangkat untuk mengidentifikasi cell (melibatkan frekuensi dan waktu) dalam prosedur handover[4]. 


\section{HASIL DAN PEMBAHASAN}

Pada saat handover terdapat beberapa faktor yang dapat menyebabkan terjadinya kegagalan. Faktor-faktor yang menyebabkan kegagalan handover antara lain: Peningkatan jumlah panggilan (call_attemp) Jumlah panggilan (call_attemp) yang berlangsung dalam sistem komunikasi selular dapat mempengaruhi tingkat kegagalan yang terjadi pada handover. Interferensi Gangguan yang disebabkan karena adanya sinyal lain yang tidak dikehendaki yang frekuensinya sama atau hampir sama dan dayanya cukup besar yang masuk bersama dengan sinyal yang seharusnya diterima. Dalam sistem komunikasi selular dapat dimungkinkan terjadi penggunaan frekuensi yang sama pada dua atau lebih kanal. Sehingga dapat mempengaruhi proses handover yang berlangsung. Propagasi Propagasi adalah pelemahan yang diperkirakan akan dialami sinyal dari Base Transceiver Station (BTS) ke User Equipment (UE). Hal ini disebabkan adanya pergerakan dari UE yang menyebabkan kuat sinyal yang diterima UE bervariasi. Fading Perubahan kuat sinyal yang terjadi akibat gangguan propagasi, seperti adanya pemantulan yang disebabkan oleh kontur alam, gedung, rumah dan lain-lain. Akan tetapi penyebab kegagalan handover yang sering terjadi yaitu strategy neigbouring yang kurang baik, sebagai contoh dapat lihat gambar dibawah ini :

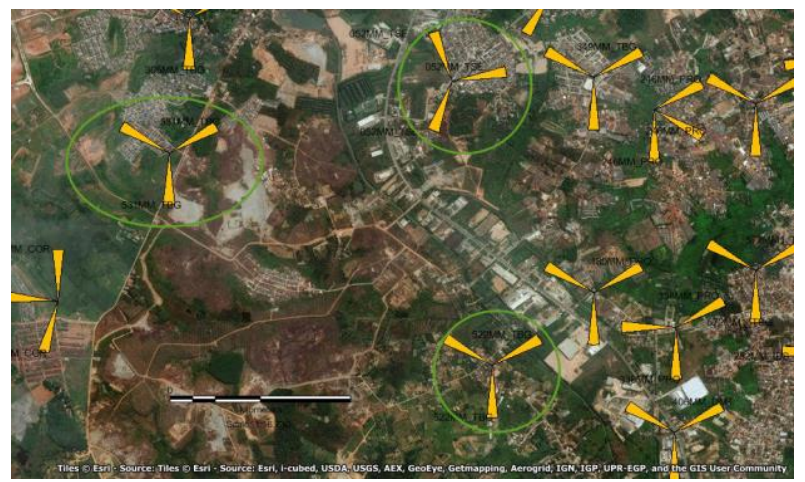

Gambar 2. Strategi yang Kurang Baik pada Jaringan 4G

\subsection{Drive Test pada Peristiwa Handover}

Drive test dilakukan secara berkala untuk terus memonitoring kondisi jaringan sehingga sesuai dengan standar yang telah ditetapkan perusahaan. Drive Test PT.Metro Global Service menggunakan bantuan software GENEX Probe karena sifatnya yang user friendly dan mudah untuk digunakan. Biasanya Drive Test dilakukan sebanyak satu kali dalam satu bulan (monthly), atau dalam kondisi tertentu seperti adanya permasalahan jaringan, berlangsungnya sebuah event, dan perpanjangan kontrak penempatan site.

Pada bagian ini diberikan hasil penelitian yang dilakukan sekaligus dibahas secara komprehensip. Hasil bisa berupa gambar, grafik, tabel dan lain-lain yang mempermudah pembaca paham dan diacu di naskah. Jika bahasan terlalu panjang dapat dibuat sub-sub judul, seperti contoh berikut. 


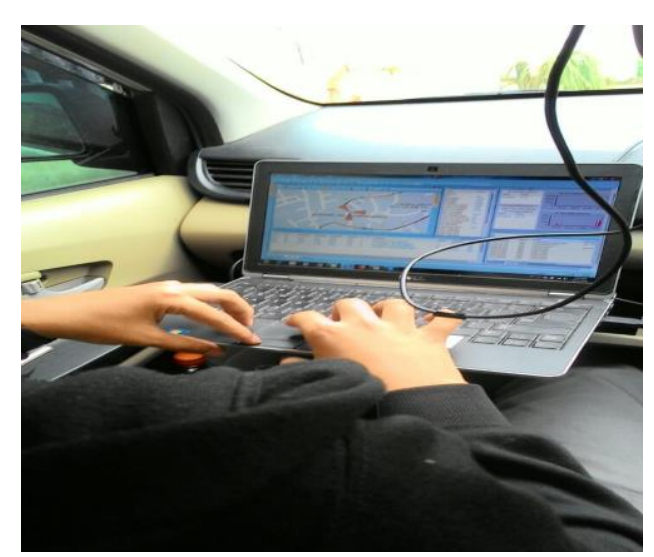

Gambar 3. Kegiatan Drive Test

Setelah melakukan pengambilan data dilapangan dan dianggap selesai tim Drive Test PT.Metro Global Service melakukan Drive Test Verification.

Berikut tahapan yang dilakukan dalam melakukan drive test verification:

1. Klik menu New Project untuk menampilkan data hasil drive test sebelumnya.

2. Masukkan file drive test tersebut yang telah tersimpan di folder, Klik Ok.

3. Kemudian Klik Logfile Manager.

4. Setelah Logfile Manager terbuka maka Klik Add File lalu Klik OK.

5. Klik icon Analysis Group Manager.

6. Jika Analysis Group Manager sudah terbuka maka Klik Add.

7. Setelah itu Klik toolbar >> , lalu Klik OK.

8. Klik Ok pada tampilan Analysis Group Manager dibawah ini.

9. Setelah itu Double Klik pada folder All Logs, lalu Klik Ok untuk menjalankan analisis.

10. Kemudian cari folder LTE pada UE di toolbar All Logs. Klik folder LTE tersebut.

11. Pada folder LTE, Klik bagian Serving and Neighbor, lalu Klik Serving PCI, kemudian Double Klik pada icon Serving PCI.

12. Berikut adalah tampilan hasil drive test untuk verification.

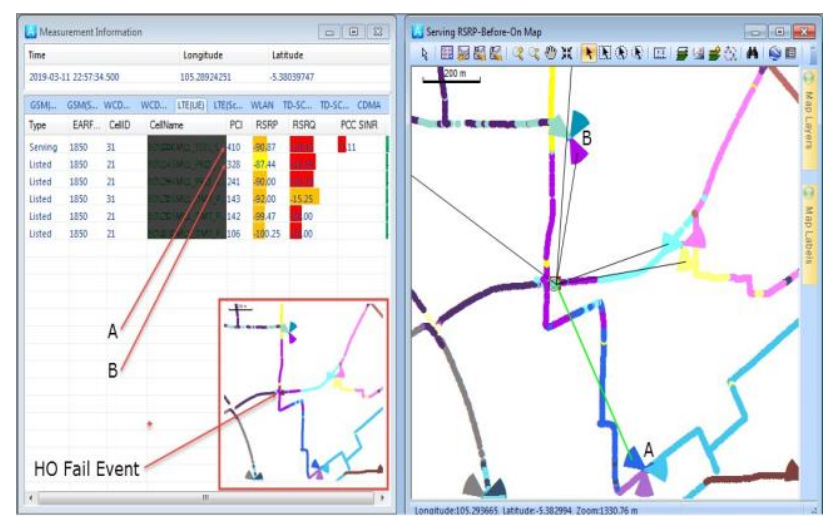

Gambar 4. Tampilan Hasil Drive Test 


\subsection{Physical Tuning}

Physical tuning merupakan metode optimalisasi di mana optimalisasi dilakukan dengan mengubah atau mengatur perangkat fisik pada jaringan yang ada di lapangan. Physical tuning yang dapat dilakukan adalah tilting, adjustment height atau mengatur ulang tinggi antena, adjustment azimuth antena dan lain sebagainya. Tilting merupakan pengarahan sudut elevasi pada antena.Tujuan dari tilting adalah agar pancaran antena mengarah pada coverage area yang seharusnya atau dominance area.

\subsubsection{Rigger}

Pemanjat tower yang bertugas merubah parameter dan posisi antena BTS. Peralatan rigger tersebut meliputi, Tilt Meter, Kompas, Kamera, Saftybelt, Body Harnes, Kunci 13, 14 dan kunci bunga.

\subsubsection{Tilting}

Instalasi BTS operator melakukan instalasi suatu antena untuk tujuan coverage agar operator bisa optimal dalam memenuhi kebutuhan konsumen. Pada saat instalasi antena inilah operator "bersentuhan" dengan istilah Tilting. Tilting sendiri diartikan sebagai suatu pengaturan kemiringan antena yang berfungsi untuk menetapkan area yang akan menerima cakupan sinyal serta untuk menentukan/mengubah coverage area yang akan di layani oleh BTS inilah biasanya operator melakukan teknik tilting, dimana operator bisa mengubah arah atau kemiringan antena.

Tilting itu sendiri dibagi menjadi 2 jenis yaitu Mechanical Tilting dan Elektrical Tilting. Mechanical tilting adalah mengubah arah atau kemiringan antena dengan cara mengubahnya dari sisi fisik antena. Rigger memiliki alat ukur tilt meter yang memperlihatkan derajat kemiringan antena. Electrical tilting adalah mengubah coverage antena dengan cara mengubah fasa antena, sehingga terjadi perubahan pada beamwidth antena. Mengubah fasa dapat dilakukan dengan mengubah settingan electrical tilt pada antena. Pengaturan elektrikal tilt biasanya terletak dibawah antena[5].

\subsection{Optimalisasi Handover Jaringan 4G Telkomsel}

Kegiatan optimalisasi dilakukan untuk menghasilkan kualitas jaringan yang baik dalam suatu daerah dengan menggunakan data yang tersedia seefisien mungkin. Ada beberapa hal yang harus diperhatikan ketika optimalisasi jaringan yaitu:

a. Menemukan dan selanjutnya memperbaiki masalah yang ada setelah implementasi dan integrasi site yang bersangkutan.

b. Harus dilakukan secara berkala guna meningkatkan kualitas suatu jaringan secara menyeluruh.

c. Optimaliasi sebaiknya tidak sampai menurunkan kinerja jaringan yang lainnya.

d. Dilakukan pada cakupan daerah yang lebih kecil yang disebut dengan cluster agar optimalisasi jaringan dapat segera dilakukan. 
Optimalisasi merupakan langkah penting dalam siklus hidup suatu jaringan. Proses awal yang dilakukan adalah melakukan drive test yang bertujuan mengumpulkan data pengukuran daerah tertentu. Setelah data terkumpul langkah selanjutnya adalah melakukan analisis untuk mengatasi permasalahan yang terjadi kemudian mengambil tindakan optimalisasi. Kegiatan optimalisasi yang langsung dapat dilakukan setelah drive test yaitu:

1. Spot 1

Coverage Buruk karena tidak ada layanan dari situs terdekat (KOT099)

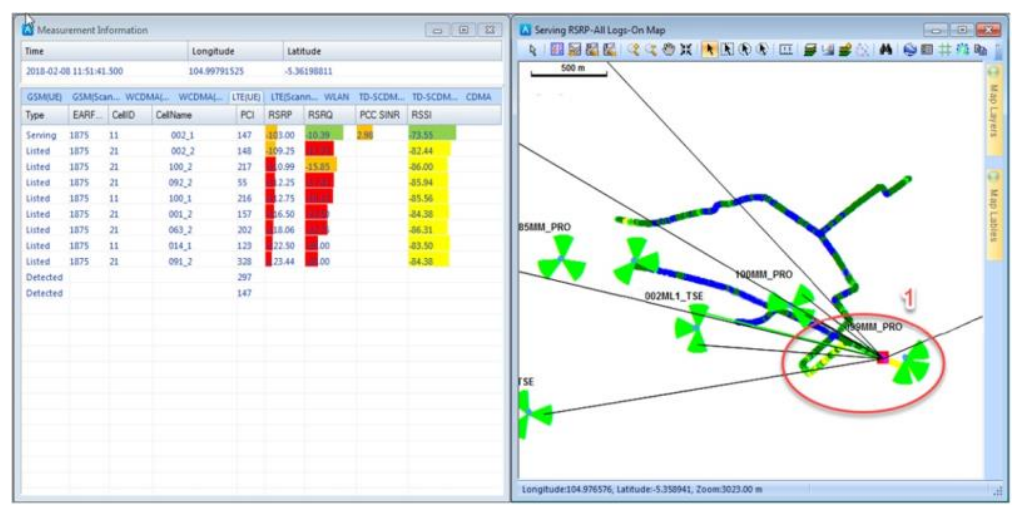

Gambar 5. Coverage Buruk SPOT 1

Tindakan:

Physcal tuning KOT100 uptilt sektor 2

2. Spot 2

Analisa: Coverage Buruk karena tidak ada layanan dari situs terdekat (KOT099), Overshoot dari COB002.

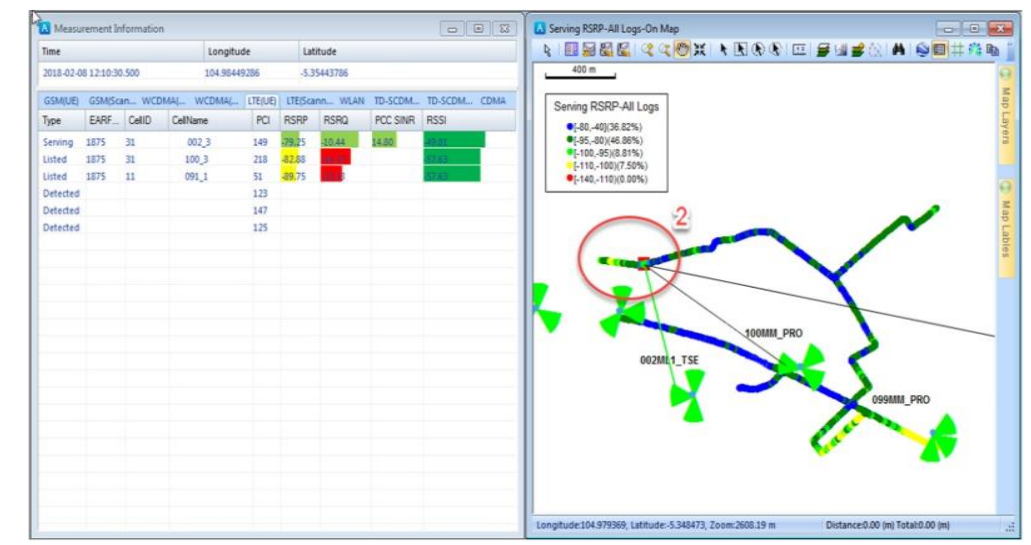

Gambar 6. Coverage Buruk SPOT 2

Tindakan:

Physcal tuning COB002 untuk memeriksa kemiringan dan kemiringan aktual. 


\section{Spot 3}

Analisa: Kualitas Buruk karena gangguan dari KOT091 sektor 2 dan KOT 001 sektor 1

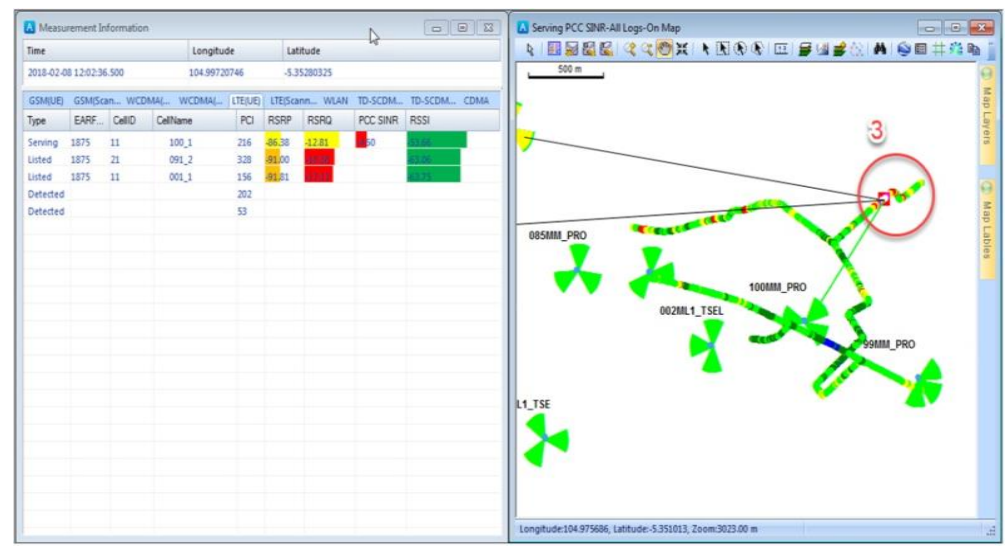

Gambar 7. Kualitas Buruk di SPOT 3

Tindakan:

Physcal tuning KOT091 downtilt sektor 2

4. Spot 4

Analisa: Kualitas Buruk karena tidak ada layanan dari situs terdekat (KOT152), Overshoot dari COB002 sektor 3, Overshoot dari KOT100.

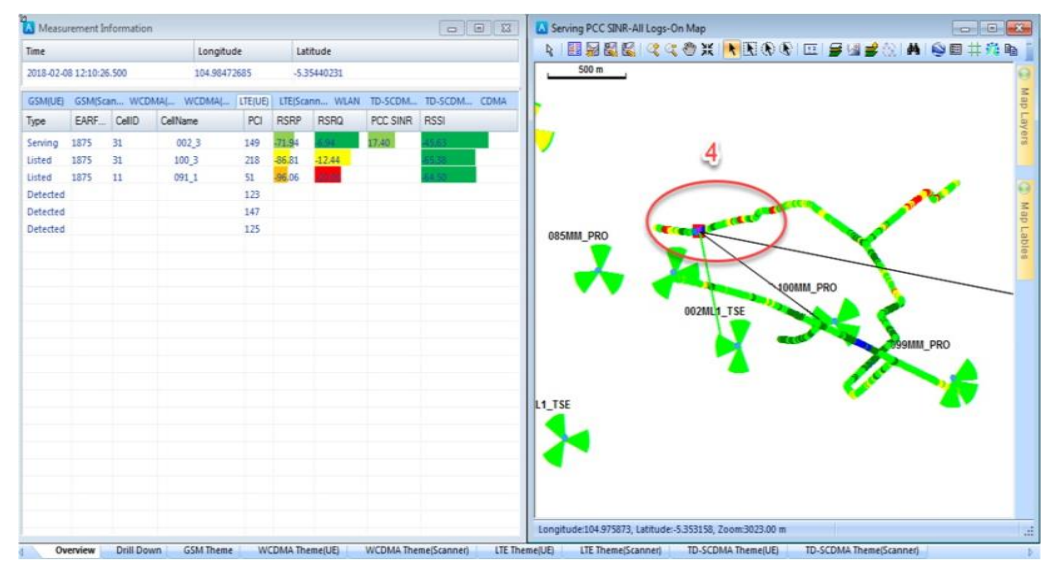

Gambar 8. Kualitas Buruk di SPOT 4

Tindakan:

Physcal tuning COB002 untuk memeriksa kemiringan dan kemiringan aktual.

Berdasarkan analisis dan optimalisasi di atas maka dapat hasil yang diharapkan sebagai berikut: 
Jurnal Riset Sistem Informasi Dan Teknik Informatika (JURASIK)

Volume (4) Juli 2019, pp 117-126

ISSN: 2527-5771/EISSN: 2549-7839

http://tunasbangsa.ac.id/ejurnal/index.php/jurasik

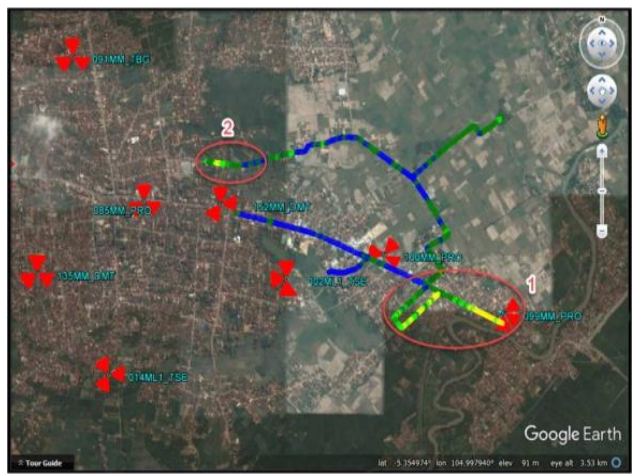

Before

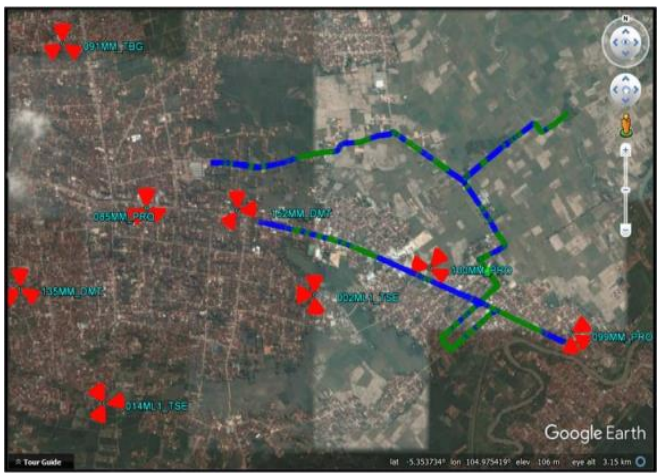

After

Gambar 9. Perbandingan RSRP Before dan After Optimalisasi

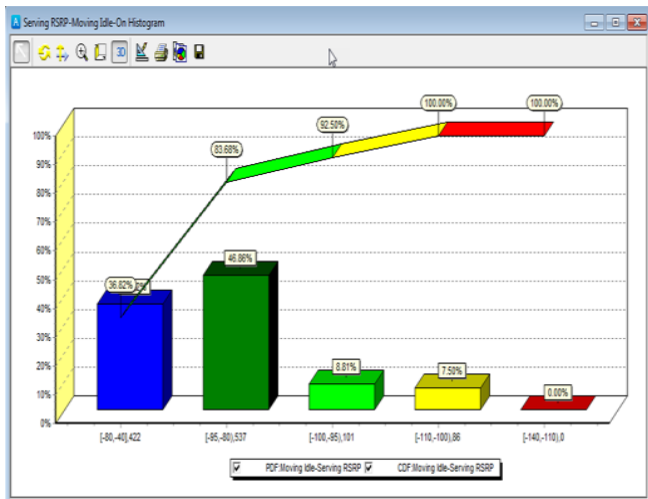

Before

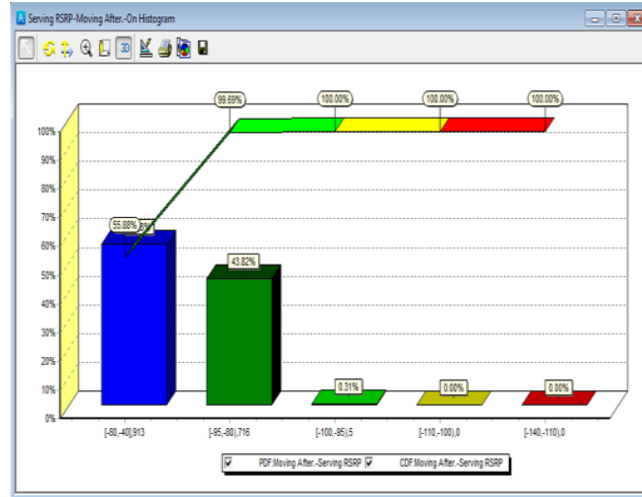

After

Gambar 10. Perbandingan RSRP Before dan After Optimalisasi pada Histogram

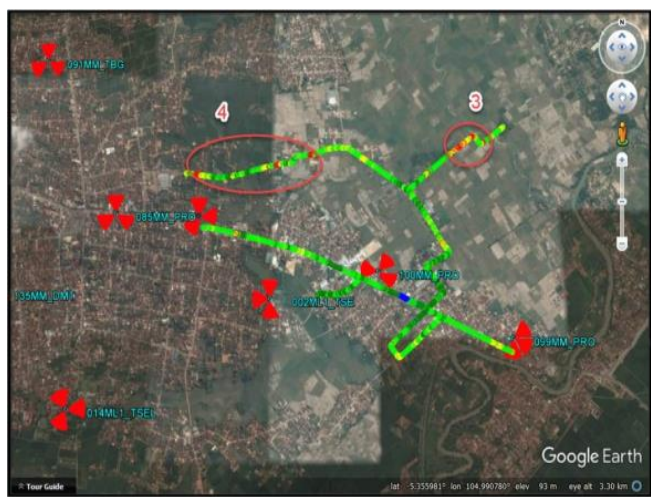

Before

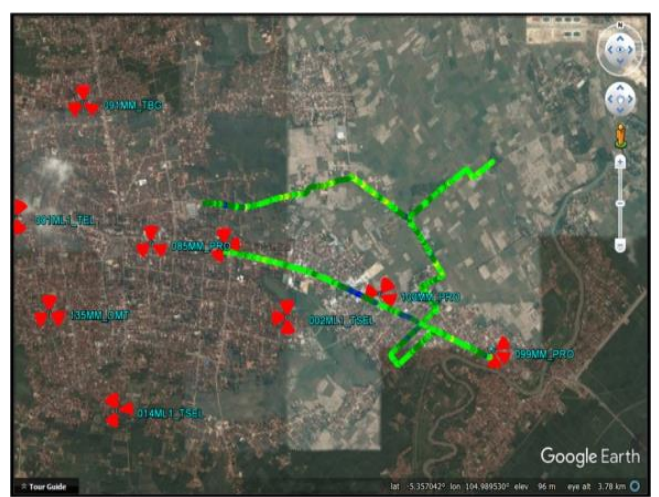

After

Gambar 11. Perbandingan SINR Before dan After Optimalisasi 


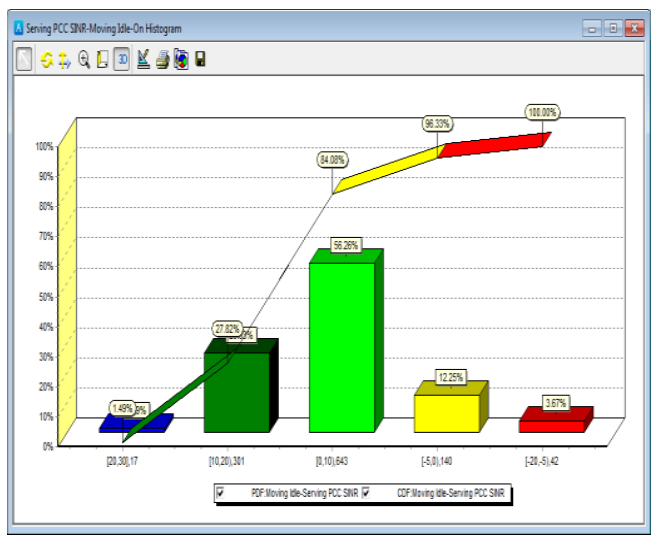

Before

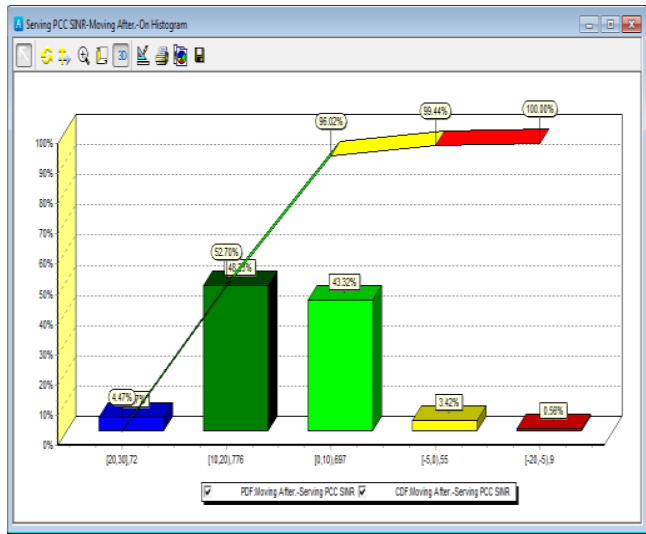

After

Gambar 12. Perbandingan RSRP Before dan After Optimalisasi pada Histogram

\section{SIMPULAN}

Setelah melakukan drive test kemudian menganalisa peristiwa handover serta mengambil tindakan opimalisasi, maka didapatkan kesimpulan sebagai berikut :

1. Mengambil data pada BTS yang bermasalah dengan melakukan drive test, setelah itu data tersebut di analisa untuk mendapatkan tindakan selanjutnya.

2. Pada Spot 1 dan Spot 2 Coverage RSRP buruk karena tidak ada layanan dari situs terdekat.

3. Pada Spot 3 dan Spot 4 Kualitas SINR buruk karena mendapatkan gangguan dan tidak ada layanan dari situs terdekat.

4. Melakukan Physcal Tuning sebagai Optimalisasi pada peristiwa handover sehingga handover dapat berjalan dengan baik serta kepuasan pelanggan tetap terjaga.

\section{DAFTAR PUSTAKA}

[1] Bursandy, Azimi, 2017. Analisis Kinerja Jaringan 4G Long Term Evolution di Sumbagsel Studi Kasus pada PT.Telkomsel Regional ICT Opertaion Sumbagsel dengan Metode Global Frequency Retunning. Palembang: Politeknik Negeri Sriwijaya

[2] Indah Ayu Lestari, Ali Nurdin, Asriyadi, 2017. "Analisis Manajemen Interferensi Jaringan Uplink 4G-LTE dengan Metode Innerloop Power Control di PT Telkomsel", (ISBN : 978-6021180-50-1).

[3] A. L. Imoize, O. D. Adegbite,"Measurement-Based performance Analysis of a 4G LTE Network in and Around Shopping Malls and Campus Environments in Lagos Nigeria", Vol.1, No.2, June 2018 (ISSN: 2545-5818).

[4] Maria Ulfah, Perfomansi Parameter Carrier to Noise Interference Ratio $(C / N+I)$ terhadap Penggunaan Metode Physical Cell Identitiy (PCI) Teknologi 4G LTE 1800 MHz, Vol.5, No.1, April 2019 (ISSN: 2477-5525).

[5] Akpado K.A, dkk," Investigating the Impacts of Base Station Antenna Height, Tilt and Transmitter Power on Network Coverage", Vol.2, No.7, July 2013 (ISSN: 2319-6734). 